\title{
Od zaangażowanego uczestnictwa do biernego krytykanctwa. Aktywność, oceny i opinie nauczycieli z pogranicza polsko-czeskiego
}

\section{STRESZCZENIE}

Realizowane na reprezentatywnej grupie Polaków cykliczne badania sondażowe wskazują na zmiany następujące w polskim społeczeństwie - zmienia się nastawienie Polaków do własnej aktywności nieprzynoszącej dochodów, ale mającej znaczenie ogólnospołeczne. Rosnące społeczne zaangażowanie jest bez wątpienia zjawiskiem pozytywnym. Zagadnieniem, które interesuje mnie od lat jest sprawa aktywności i zaangażowania nauczycieli - zwłaszcza mieszkających na pograniczu polsko-czeskim. Pogranicze to przestrzeń sprzyjająca wzmożonej aktywności i zaangażowaniu. Działania transgraniczne są w dużej mierze adresowane do szkół i nauczycieli, a współpraca rozwija się na badanym terenie południowego pogranicza bardzo intensywnie. Inspiracją do przeprowadzenia badań były realizowane wcześniej projekty adresowane do nauczycieli z obu stron granicy. Chciałam sprawdzić, czy poglądy reprezentowane przez nauczycieli zaangażowanych w projekty są zbliżone do tych podzielanych przez szerszą, reprezentatywną grupę osób pracujących w szkołach. W opracowaniu uzyskanych danych empirycznych zastosowane zostały metody statystyczne: testowanie statystycznej istotności różnic między zmiennymi wykonano za pomocą testu chi-kwadrat ( $x 2$ ), a do zmierzenia siły związku między zmiennymi użyto współczynnika V Cramera $(0 \leq V \leq 1)$. Interesowała mnie aktywność badanych nauczycieli w zakresie udziału w projektach transgranicznych oraz poszukiwania wiedzy o sąsiadach. Chciałam się również dowiedzieć, jak oceniają aktywność innych

1 Anna Szafrańska, Wydział Etnologii i Nauk o Edukacji, Uniwersytet Śląski w Katowicach, Polska, anna.gajdzica@us.edu.pl. 
podmiotów - polityków różnych szczebli oraz stowarzyszeń i instytucji edukacyjnych, w sferze nawiązywania bliższych kontaktów między Polakami a Czechami. Analizy uzyskanych wyników badań w zakresie oceny działań podejmowanych przez różne podmioty pod kątem nawiązywania kontaktów transgranicznych wskazują na duży krytycyzm badanych. Warto przy tym zauważyć, że sami badani wykazują niewielkie zainteresowanie działaniami związanymi z nawiązywaniem kontaktów polsko-czeskich.

\section{Słowa kluczowe:}

nauczyciel, pogranicze, projekty transgraniczne, zaangażowanie, politycy, krytyczna ocena

\section{ABSTRACT}

The cyclic survey, carried out on a representative group of Poles, indicate some changes taking place in the Polish society - what has changed is Poles' attitude to their own activity which brings no profit but is of general social significance. With no doubt, growing social engagement is a positive phenomenon. The issue which the author has explored for years is the activity and engagement of teachers - especially those inhabiting the Polish-Czech borderland. Borderland is a space which enhances intensive activity and engagement. Transfrontier activities are largely addressed to schools and teachers and the cooperation in the examined area of the southern borderland is very intensive. The research was inspired by earlier projects addressed to teachers on both sides of the border. Its aim was to find out whether the views of teachers engaged in projects are close to the views shared by a broader, representative group of school workers. The obtained empirical data were processed with the use of statistical methods: for testing the statistical significance of differences between variables the chi-square test $(x 2)$ was used, and for measuring the intensity of the relation between variables - Cramer's $\mathrm{V}$ coefficient $(0 \leq V \leq 1)$. The research focus was on the surveyed teachers' activeness concerning both the participation in transfrontier projects and the search for knowledge of the neighbours. The research was also aimed at finding out how the teachers evaluate the activeness, in the field of establishing closer contacts between Poles and Czechs, of other subjects - politicians of all levels and educational institutions or associations. The analyses of the research results concerning this issue reveal the respondents' strong criticism. It seems worth mentioning, that the respondents themselves present little interest in the activities aimed at establishing closer Polish-Czech contacts.

\section{Keywords:}

teacher, borderland, transfrontier projects, engagement, politicians, critical evaluation 
Realizowane na reprezentatywnej grupie Polaków cykliczne badania sondażowe wskazują na zmiany następujące w polskim społeczeństwie - zmienia się nastawienie do własnej aktywności nieprzynoszącej dochodów, ale mającej znaczenie ogólnospołeczne (Komunikat z badań CBOS..., 2014)². Dwie trzecie badanych (65\%) uważa, że w dzisiejszych czasach trzeba być bardziej wrażliwym i gotowym do pomocy innym ludziom (Komunikat z badań CBOS. Potencjał społecznikowski..., nr 15/2016), przy czym ten odsetek minimalnie spadł w 2016 r. (Komunikat z badań CBOS. Potencjał społecznikowski..., nr 15/2016, s. 5) w stosunku do poprzedniego okresu badań (Komunikat z badań CBOS..., 2014, s. 5). Systematycznie wzmacnia się też przekonanie Polaków o skuteczności wspólnego działania zwykłych ludzi, możliwości rozwiązywania problemów lokalnych (Komunikat z badań CBOS..., 2014, s. 6-7)3. Uzyskiwane dane pozwalają na stwierdzenie, że zgodnie z deklaracjami Polaków, systematycznie rośnie zaangażowanie w pracę społeczną w organizacjach obywatelskich. Coraz więcej Polaków wykazuje zainteresowanie sprawami wykraczającymi poza sferę prywatną i zawodową. Działalności społecznej i aktywności w organizacjach sprzyjają takie czynniki jak wyższe wykształcenie, znacząca pozycja zawodowa, bezpieczeństwo finansowe, a także zaangażowanie religijne i zamieszkiwanie w dużych miastach (Komunikat z badań CBOS. Aktywność Polaków..., nr 13/2016, s. 12). Zagadnieniem, które interesuje mnie od lat jest sprawa aktywności i zaangażowania nauczycieli - zwłaszcza mieszkających na pograniczu polsko-czeskim. Rosnące społeczne zaangażowanie jest bez wątpienia zjawiskiem pozytywnym. Przedmiotem moich badań nie była ogólna aktywność, lecz specyficzna - dotycząca wchodzenia w kontakty z południowym sąsiadem, poszukiwania o nich wiedzy, uczestniczenia we wspólnych projektach. Jednocześnie interesowało mnie, jak oceniają badani zaangażowanie w tą sferę innych podmiotów - polityków czy instytucji edukacyjnych.

2 Badanie „Aktualne problemy i wydarzenia” przeprowadzono metodą wywiadów bezpośrednich (face-to-face) wspomaganych komputerowo (CAPI) w dniach 6-12 marca 2014 r. na liczącej 1098 osób reprezentatywnej próbie losowej dorosłych mieszkańców Polski.

3 O ile w 2002 r. 50\% respondentów zgadzało się z tezą: „Ludzie tacy jak ja, działając wspólnie z innymi, mogą pomóc potrzebującym lub rozwiązywać niektóre problemy swojego środowiska, osiedla, wsi lub miasta”, to już w 2014 r. taki pogląd popierało 77\% badanych. 


\section{POGRANICZE JAKO PRZESTRZEŃ DO PODEJMOWANIA AKTYWNOŚCI PRZEZ NAUCZYCIELI}

Pogranicze to kategoria będąca przedmiotem zainteresowania wielu dyscyplin naukowych. W efekcie doczekała się licznych rozstrzygnięć teoretycznych na gruncie filozofii, ekonomii, polityki, socjologii czy pedagogiki. Właśnie na potrzeby refleksji pedagogicznej Pogranicze zostało opisane przez L. Witkowskiego w szerszej, interdyscyplinarnej perspektywie. Autor dokonał reinterpretacji filozoficzno-estetycznej koncepcji M. Bachtina i uwzględnił cztery aspekty (rozumienia) ontologii „bycia między”: pogranicze rozumiane jako przestrzeń, terytorium; nasycenie charakterem interakcyjnym; dookreślenie w kontekście różnic i podobieństw (relacji) oraz jako generowane przez ambiwalentny status uczestniczących w nim członków sytuacji kulturowej, podmiotów czy kategorii deskryptywnych (Witkowski, 1991). Pogranicze stwarza zatem „(...) szansę na taki sytuacyjny i oscylujący między bliskością i oddaleniem dystans, który uprzedmiatawiając zastane intencjonalności (jednostek i zbiorowości) przyczyni się do pogłębienia podmiotowości i zwiększenia ich kompetencji do radzenia sobie ze złożonością otoczenia, a w istocie ze złożonością (także jako ukrytym i niewykorzystanym bogactwem) własnego losu” (Witkowski, 1995, s. 18). Na potrzeby prezentowanych analiz przyjęłam rozumienie pogranicza w ujęciu terytorialnym. Pogranicze to obszar, wspólna przestrzeń, na której funkcjonują dwie lub więcej grupy etniczno-kulturowe. Formy współżycia ukształtowane są poprzez bycie obok - styczność z sobą i wzajemne kontakty (Sadowski, 2008).

Prezentowane w tekście badania zostały przeprowadzone na pograniczu polsko-czeskim. Pogranicze to przestrzeń sprzyjająca wzmożonej aktywności i zaangażowaniu - zwłaszcza, że od szeregu lat działania wielu instytucji są mocno promowane w regionie poprzez umowy transgraniczne i możliwości pozyskiwania środków na różne cele o charakterze społecznym. Działania transgraniczne są w dużej mierze adresowane do szkół i nauczycieli, a współpraca rozwija się na terenie powiatu cieszyńskiego bardzo intensywnie (Böhm, 2015, 2017). Aktywność oznacza przejawianie inicjatywy, branie udziału. W realizowanych wcześniej badaniach wśród nauczycieli przyjęłam, że aktywność jest komponentem rozwoju indywidualnego, społecznego i zawodowego (Gajdzica, 2013, s. 43-48). Jest to moralno-wolicjonalna właściwość osobowości jednostki, która ujawnia się w momencie podejmowania działań o charakterze celowym, które prowadzą do rozwiązywania zadań (społecznych i indywidualnych). Charakter aktywności jest zazwyczaj kompleksowy. Może być zatem incydentalny lub stały. Pierwszy z nich oznacza podejmowanie działań o charakterze jednostkowym, najczęściej mającym 
podłoże emocjonalne. Z kolei aktywność stała oznacza cykliczne podejmowanie działań i najczęściej związane jest z działaniami w organizacjach, stowarzyszeniach. „Aktywność indywidualna jest wyrazem zdolności do autonomicznego działania, odzwierciedleniem poczucia własnej wartości, egzemplifikacją swojego „ja” wewnętrznego, zdolności twórczych, gotowości do podejmowania działań w zespole, ale również indywidualnie. Rzutuje na obszar aktywności społecznej i zawodowej, które są jej pochodną” (tamże, s. 43).

Mieszkanie i praca na pograniczu sprzyja podejmowaniu aktywności mającej na celu poznanie sąsiada. Jest to ważne zwłaszcza w sytuacji pracy z młodym pokoleniem. Nauczyciele mają możliwość budowania wizerunku sąsiada, kształtowania pozytywnych postaw mających na celu przełamywanie stereotypów i uprzedzeń wśród dzieci i młodzieży. Żeby tak jednak mogło być, sami powinni posiadać wiedzę na temat sąsiadów, mieć możliwość ich poznania. Relacje na Pograniczu są zależne od wielu czynników. Część z nich związana jest z działaniami podejmowanymi indywidualnie przez poszczególne osoby, inne są inicjowane, promowane i realizowane przez różnego rodzaju instytucje, organizacje, związki i stowarzyszenia. Pogranicze - o czym jednak należy pamiętać - zawsze obarczone jest wspólną historią, która te kontakty może zaburzać. Wprawdzie - zwłaszcza z perspektywy osób mieszkających poza terenem południowego pogranicza - jest to obszar, w którym mniej jest niełatwych doświadczeń przeszłości, jednak co podkreśla H. Rusek, to jest to trudne sąsiedztwo (2004, s. 106). W przeszłości był to bowiem obszar szczególnie licznych konfliktów, sporów terytorialnych i ideologicznych, a także wzajemnego napiętnowania. W XX w. można było z kolei obserwować ostrą polsko-czeską rywalizację o przywództwo w Europie Środkowej, szczególnie intensywne w okresie międzywojennym.

Teren południowego pogranicza różni się w zdecydowany sposób od wschodniego pogranicza Polski. Umowa Schengen gwarantuje swobodę przemieszczania się (MSWiA, Strefa Schengen), co z kolei sprzyja nawiązywaniu kontaktów indywidualnych, wymianie ekonomicznej, kulturowej. Dodatkowo w Polsce od lat można zaobserwować zainteresowanie naszymi południowymi sąsiadami. Dużą popularnością cieszą się popularyzujące wiedzę o Czechach publikacje (Mazan, 2007; Szczygieł, 2006, 2010, 2012; Surosz, 2010)4, a także blogi (Czechofil) czy strony na popularnych portalach społecznościowych5 ${ }^{5}$. Sprzyja to budowaniu

4 Na polskim rynku księgarskim dostępnych jest też bardzo wiele pozycji czeskich autorów - liczne wznowienia takich klasyków jak Bohumil Hrabal, Milan Kundera czy Karel Čapek, ale również mniej znanych, jak Ota Pavel czy Evžen Boček.

5 Po. strona na facebooku, która w dniu 5 maja miała 7276 polubień: https://web.facebook. com/czechofile/?_rdr (18.01.2017). 
pozytywnego wizerunku Czech i Czechów ${ }^{6}$. Czy jednak faktycznie ta bliskość powoduje, że nawiązujemy kontakty partnerskie? Na ile w dalszym ciągu opieramy się na stereotypach, a w jakim zakresie poszukujemy faktycznie wiedzy o sąsiedzie? Organizowane przeze mnie warsztaty z nauczycielami szkół średnich pracującymi na pograniczu polsko-czeskim dostarczyły licznych dowodów na to, że mimo upływu lat bez fizycznej granicy dominuje stereotypowe spostrzeganie sąsiadów. Interesowało mnie, jaki jest stosunek do współpracy i do sąsiadów nauczycieli - niekoniecznie angażujących się w takie działania.

\section{ZAŁOŻENIA METODOLOGICZNE BADAŃ}

Badania zostały przeprowadzone na terenie pogranicza polsko-czeskiego. Możemy obserwować zróżnicowane sposoby budowania współpracy międzysąsiedzkiej, a także wykorzystania przez mieszkańców potencjału pogranicza w poszczególnych częściach strefy granicznej ${ }^{7}$ Bez wątpienia, zwłaszcza w tym drugim, indywidualnym przypadku, sposoby zachowania warunkowane są społeczno-kulturowymi doświadczeniami przeszłości. Współpraca jest realizowana zarówno na szczeblu samorządowym, jak i oddolnie w inicjatywach związanych z środowiskiem lokalnym (stowarzyszenia, instytucje społeczne itd.). Wybór powiatu cieszyńskiego jako miejsca badań był celowy. Trzykrotnie koordynowałam projekty transgraniczne polegające na organizacji wspólnych działań dla nauczycieli z Polski i Republiki Czeskiej. Za każdym razem projekty cieszyły się ogromnym zainteresowaniem ze strony polskich nauczycieli, co przekładało się na szybki nabór, wysokie oceny w trakcie projektów, a po zakończeniu projektów na sygnały od uczestników wskazujące na chęć udziału w kolejnym tego typu działaniu. To zainteresowanie nauczycieli, ich zaangażowanie w proponowane działania oraz opinie na temat korzyści ze wspólnej pracy nauczycieli z obu stron granicy stało się inspiracją do przeprowadzenia badań na szerszej grupie nauczycieli. Chciałam sprawdzić, czy poglądy reprezentowane przez nauczycieli zaangażowanych w projekty są zbliżone do tych podzielanych przez szerszą, reprezentatywną grupę osób pracujących w szkołach.

6 Jest to jednak zainteresowanie w dużej mierze jednostronne. Trudno bowiem znaleźć na rynku czeskim odpowiedniki wskazujące na podobne zainteresowanie Czechów Polakami i Polską.

7 Granica z Republiką Czeską jest najdłuższą granicą Polski - obejmuje 796 km. Wzdłuż granicy zostało wydzielonych sześć Euroregionów, które łączą ze sobą nie tylko uwarunkowania geograficzne, ale również wspólna historia, podobne uwarunkowania społeczne i ekonomiczne. 
Łącznie na badanym terenie zostało rozdanych 600 ankiet, a ostatecznej analizie poddano 118 kwestionariuszy (część kwestionariuszy odrzucono ze względu na niekompletne dane, dużo kwestionariuszy nie zostało zwróconych). Badana grupa jest reprezentatywna, a wyniki przeprowadzonych badań poddano analizie ilościowej ${ }^{8}$. W opracowaniu uzyskanych danych empirycznych zastosowane zostały metody statystyczne: testowanie statystycznej istotności różnic między zmiennymi wykonano za pomocą testu chi-kwadrat ( $x 2)$, a do zmierzenia siły związku między zmiennymi użyto współczynnika V Cramera $(0 \leq V \leq 1)$. Zastosowano program do analizy statystycznej zawarty w komputerowym pakiecie STATISTICA 10PL (Lauszniewicz, Słaby, 2008).

W grupie osób badanych dominowały kobiety, które stanowiły 87,4\%; mężczyźni 5,0\%; część osób nie zaznaczyło płci (7,6\%). Większość badanych osób mieszka na wsi (54,4\%), w mieście 29,8\% (ta zmienna została uwzględniona w sytuacji analizy aktywności nauczycieli w projektach transgranicznych).

Celem prezentowanych wyników badań było poznanie deklaracji nauczycieli mieszkających na pograniczu polsko-czeskim na temat ich udziału w projektach transgranicznych, a także rozpoznanie ich oceny aktywności - w zakresie nawiązywania bliższych kontaktów między Polakami a Czechami innych podmiotów polityków różnych szczebli oraz stowarzyszeń i instytucji edukacyjnych.

\section{ZAANGAŻOWANIE WŁASNE NAUCZYCIELI W DZIAŁANIA TRANSGRANICZNE A OCENA AKTYWNOŚCI INNYCH PODMIOTÓW W TYM ZAKRESIE}

Czesi są od lat wskazywani jako jeden z najbardziej lubianych przez nas narodów (Komunikat CBOS z badań. Stosunek do..., 2018/37). Przywoływane wcześniej odniesienia do ruchu Czechofilów potwierdzają tą tendencję. Czy jednak osoby mieszkające na pograniczu, a więc mogące mieć niemal codzienny kontakt z południowymi sąsiadami, również poszukują o nich wiedzy? Wiedza jest niezbędna, by nie posługiwać się stereotypami zarówno w życiu codziennym, jak i w przypadku badanej grupy zawodowej - nie stosować ich w pracy z dziećmi i młodzieżą. Zaledwie 17,5 \% respondentów stwierdziło, że poszukuje wiedzy na temat Czechów

8 Badania były realizowane na potrzebę szerszych analiz, ale te prezentowane w artykule nie zostały tam zawarte. Pozostałe wyniki zostały opublikowane w: Lewowicki, T., Szczurek-Boruta, A., Szafrańska, A., 2017.

9 Przy spadającej sympatii do innych narodów Czesi w dalszym ciągu mają 44\% deklaracji pozytywnych. 
i Republiki Czeskiej. Pozostali (82,5\%) zaznaczyli odpowiedź negatywną (por. Wykres 1), przy czym częściej to nauczyciele pracujący na wsi są zainteresowani Czechami. Stwierdzono słaby związek między miejscem zamieszkania (miasto/ wieś), a deklarowanym poszukiwaniem wiedzy o Czechach i Republice Czeskiej, dla której V Cramera = 0,25. Szczegółowe dane tabela 1 .

Tabela 1. Deklaracje nauczycieli na temat poszukiwania wiedzy o Czechach i Republice Czeskiej z uwzględnieniem miejsca pracy

\begin{tabular}{llll}
\hline $\begin{array}{l}\text { Miejsce } \\
\text { pracy }\end{array}$ & tak & nie & Ogółem \\
\hline miasto & 6 & 56 & 62 \\
\cline { 2 - 4 } & $9,7 \%$ & $90,3 \%$ & $100,0 \%$ \\
\hline \multirow{2}{*}{ wieś } & 12 & 29 & 41 \\
\cline { 2 - 4 } & $29,3 \%$ & $70,7 \%$ & $100,0 \%$ \\
\hline ogółem & 18 & 85 & 103 \\
\cline { 2 - 4 } & $17,5 \%$ & $82,5 \%$ & $100,0 \%$ \\
\hline
\end{tabular}

N ważnych obserwacji: 103

$\chi^{2}=6,57, \mathrm{df}=1$, dla $\mathrm{p}=0,01<0,05$

V Crammera $=0,25$

Praktycznym wymiarem współpracy transgranicznej są realizowane projekty, które dają możliwość wzajemnego zbliżenia, poznania, budowania międzykulturowej świadomości. Pozyskiwane w ramach współpracy transgranicznej środki są przeznaczane na działania o charakterze edukacyjnym. Nauczyciele i uczniowie w ramach realizowanych działań mogą poznać sytuację w placówkach edukacyjnych z drugiej strony granicy. Jest to okazja do zapoznania się z kulturą, niuansami życia społecznego, odkrywaniem wzajemnych podobieństw i uczenia się szacunku do różnic. Pytałam zatem nauczycieli, czy uczestniczyli w projektach mających na celu podejmowanie wspólnych działań przez Polaków i Czechów. Okazało się, że ponad połowa z nich (59,3\%) nigdy w takich działaniach nie brała udziału, a pozytywną deklarację złożyło 40,7\% badanych, przy czym uczestnikami projektów częściej są nauczyciele pracujący w szkołach wiejskich. Spośród nauczycieli pracujących w szkołach miejskich deklaracje uczestnictwa złożyło zaledwie 30\% badanych, podczas gdy analogiczną deklarację złożyło 51,4\% nauczycieli ze szkół wiejskich.

Można zatem stwierdzić, że bardziej aktywne w tym zakresie jest środowisko wiejskie. Ten wskaźnik może być przyjęty jako ważny z punktu widzenia aktywi- 
zacji terenów wiejskich - wskazywanych w literaturze jako bardziej zaniedbane, bierne (Piwowarski, 2000; Marzec-Holka, 2015). Tymczasem teren pogranicza, a w tym przypadku konkretnie teren powiatu cieszyńskiego, ze swoją zróżnicowaną strukturą narodowościową i religijną, sprzyja powstawaniu swoistej enklawy terenów wiejskich, które pod wieloma względami różnią się od tych w środowisku monokulturowym.

Uzyskane wyniki dają nam obraz słabego zainteresowania nauczycieli z powiatu cieszyńskiego Czechami i udziałem we wspólnych działaniach. Co ciekawe niemal wszyscy badani $(98,1 \%)$ dostrzegają korzyści z działań transgranicznych. Szczegółowe dane dotyczące poszukiwania wiedzy o sąsiadach, deklaracji udziału w projektach i dostrzeganych pozytywnych efektach projektów prezentuję na wykresie 1.

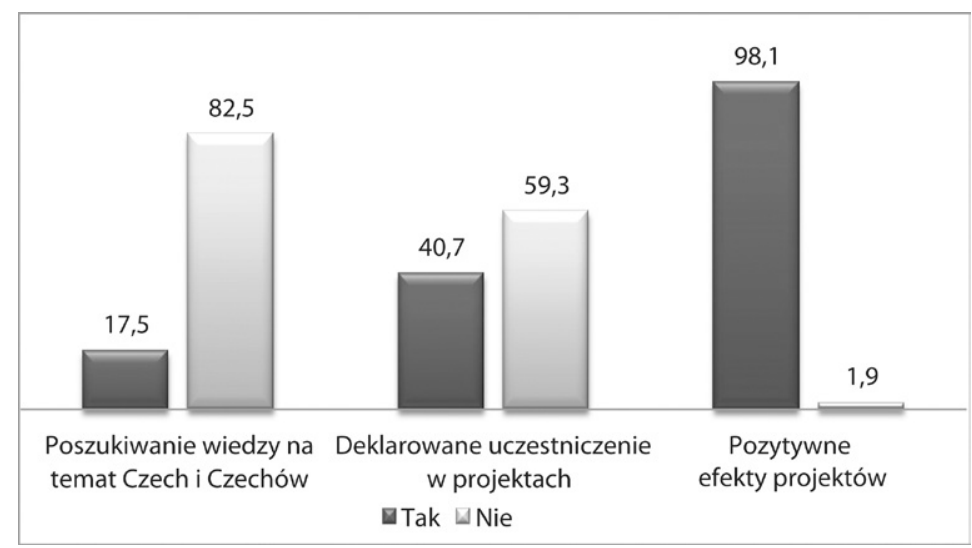

Wykres 1. Deklaracje badanych nauczycieli na temat poszukiwania wiedzy o sąsiadach, deklaracji udziału w projektach i dostrzeganych pozytywnych efektach projektów

Źródło: badania własne.

Celem współpracy transgranicznej jest zniesienie barier uniemożliwiających współpracę i zapewnienie przepływu doświadczeń pomiędzy regionami z różnych państw. Współpraca ta ma za zadanie wspieranie działań zmierzających do podniesienia jakości funkcjonowania instytucji samorządowych. Sprzyja rozwojowi turystyki, zapewnia koordynację rozbudowy infrastruktury po obu stronach granicy państwowej. Jest czynnikiem umożliwiającym kulturowy i edukacyjny rozwój regionu, a także jest narzędziem promocji. Wymienione działania i pełnione funkcje spełniane przez współpracę międzynarodową regionów sprawiają, że przyczynia się ona także do rozwoju gospodarczego (Gwizdała, 2015, s. 449-450). 
Współpraca transgraniczna powinna zatem być jednym z założeń działań realizowanych przez polityków różnych szczebli. Inne znaczenie ma to z perspektywy rządu i polityków najwyższego szczebla, inne w sytuacji działań o charakterze lokalnym. Interesowało mnie, jak badani nauczyciele oceniają działania mające na celu nawiązywanie kontaktów międzysąsiedzkich między Polakami a Czechami. Respondenci zaznaczali swoją ocenę na czterostopniowej skali. Zdecydowanie bardziej sceptyczni byli w stosunku do działań rządu i polityków najwyższego szczebla. Niemal co piąty badany nauczyciel stwierdził, że są to działania na poziomie niedostatecznym. Najliczniejsza grupa osób (59,6\%) oceniła działania na poziomie dostatecznym. Taka sama liczba osób - jak w przypadku oceny niedostatecznej - stwierdziła, że prowadzone przez rząd i polityków działania są na poziomie dobrym. Jedynie $2 \%$ respondentów przyznało ocenę bardzo dobrą. W sposób zdecydowanie bardziej pozytywny zostali ocenieni politycy lokalni. Działania związane z nawiązywaniem kontaktów międzysąsiedzkich zostały ocenione negatywnie przez $6,7 \%$, ocena dostateczna została przyznana przez $37,5 \%$ badanych, a dobra przez najliczniejszą grupę osób - 48,1\% nauczycieli. Również i w tym przypadku tylko nieliczne osoby $(7,7 \%)$ przyznały ocenę bardzo dobrą. Szczegółowe dane prezentuję na wykresie 2.

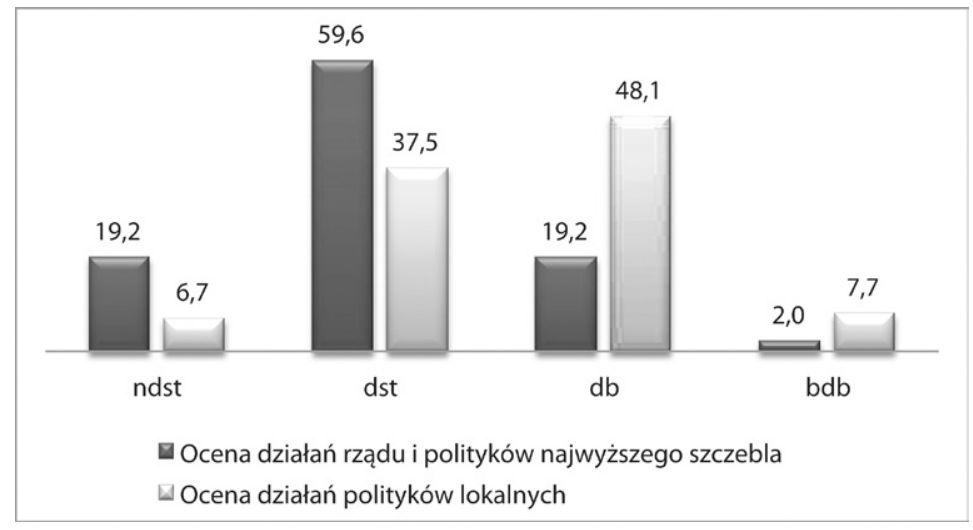

Wykres 2. Ocena przez badanych nauczycieli działań rządu i polityków najwyższego szczebla oraz polityków lokalnych w celu nawiązywania kontaktów międzysąsiedzkich (polsko-czeskich)

Źródło: badania własne.

W działania transgraniczne są zaangażowani nie tylko politycy, ale również inne podmioty. Ważne miejsce zajmują tu stowarzyszenia, które pozyskane fundusze mogą przeznaczać na wspólne działania z czeskimi partnerami, a korzyści z ich 
realizacji są bezpośrednio odczuwane przez mieszkańców. Dla nauczycieli z kolei najbardziej widoczne są te, które są podejmowane przez instytucje edukacyjne. W tym przypadku wiele szkół usytuowanych na pograniczu często aplikuje po środki, które są przeznaczane na transgraniczne zajęcia z zakresu sportu, rozwoju kultury i sztuki, umiejętności praktycznych (w tym przypadku aplikują głównie szkoły techniczne i zawodowe) czy też działania o charakterze edukacyjnym zarówno dla uczniów różnych typów szkół, jak i dla nauczycieli. Oceny działań stowarzyszeń i instytucji edukacyjnych mających na celu nawiązywanie kontaktów międzysąsiedzkich były znacznie wyższe od tych dotyczących polityków. Z pewnością inicjatywy tych podmiotów są bardziej widoczne i bezpośrednio odczuwane przez nauczycieli. Jednak i w tym przypadku część nauczycieli oceniła negatywnie zarówno aktywność stowarzyszeń (8,2\%), jak i instytucji edukacyjnych ocenianych w ten sposób przez większą liczbę osób (14,9\%). Nieznacznie częściej oceniane jako dostateczne były działania stowarzyszeń (36,7\% - podczas gdy oceny dostateczne dla działań instytucji edukacyjnych były przyznane przez 35,6\%). Z kolei jako dobre ocenione zostały częściej działania instytucji edukacyjnych (42,6\%). Znacznie częściej ocena bardzo dobra była przyznawana stowarzyszeniom (15,3\%). Szczegółowe dane prezentuję na wykresie 3.

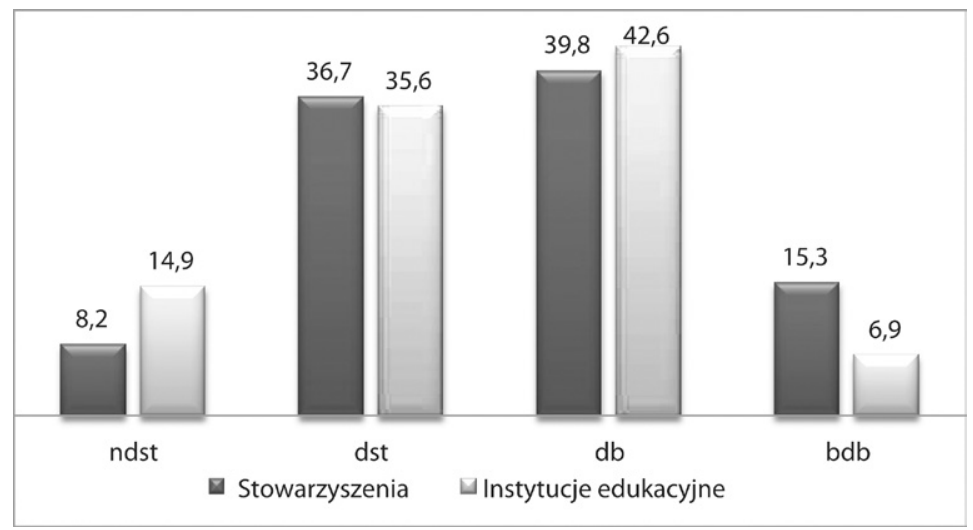

Wykres 3. Ocena przez badanych nauczycieli działań stowarzyszeń i instytucji edukacyjnych w celu nawiązywania kontaktów międzysąsiedzkich (polsko-czeskich)

Źródło: badania własne. 


\section{KONKLUZJE}

Analizy uzyskanych wyników badań w zakresie oceny działań podejmowanych przez różne podmioty w zakresie nawiązywania kontaktów transgranicznych wskazują na duży krytycyzm badanych. Najwięcej ocen negatywnych otrzymał rząd i politycy najwyższego szczebla oraz co może być zaskakujące - instytucje edukacyjne. O ile działania podejmowane centralnie mogą być niezauważalne przez mieszkańców pogranicza nie interesujących się na co dzień kwestiami legislacyjnymi czy polityką zagraniczną, o tyle działania inicjowane przez instytucje edukacyjne są tymi, które bezpośrednio dotyczą nauczycieli w ich sferze zawodowej. Działania polityków mogą być poza realnym wpływem samych badanych, jednak inicjatywy podejmowane przez instytucje edukacyjne mogą być inicjowane na szczeblu samych nauczycieli. Warto przy tym zauważyć, że sami badani wykazują niewielkie zainteresowanie działaniami związanymi z nawiązywaniem kontaktów polsko-czeskich. Nieliczni poszukują wiedzy o południowych sąsiadach i chociaż niemal wszyscy dostrzegają korzyści płynące z projektów, to uczestniczyło w nich mniej niż 50\% badanych. Udział w projektach transgranicznych jest realnym krokiem zmierzającym do likwidacji stereotypów i uprzedzeń. Ważne jest, by takie działania podejmowali nauczyciele, którzy swoją aktywnością w tym kierunku mogą zarażać również swoich uczniów.

\section{Bibliografia}

Böhm, H. (2015). Czech-Polish Borders: Comparison of the EU Funds for Cross-Border Cooperation of Schools in Selected Euroregions. In: Scott, J.W. (ed.), Yearbook-Cross-Border Review. European Institute of Territorial Co-operation (pp. 59-74). Hungary: Esztergom.

Böhm, H. (2017). Comparison of the role of the EU funds for Czech-Polish cross-border co-operation of schools. Edukacja Międzykulturowa, 1, 145-162.

Czechofil. Pobrane z: https://czechofil.com/ (5.05.2018).

Gajdzica, A. (2013). Portret zbiorowy nauczycieli aktywnych - między zaangażowaniem a oporem wobec zmian. Toruń-Cieszyn: Wydawnictwo Wydział Etnologii i Nauk o Edukacji Uniwersytetu Śląskiego, Wydawnictwo Adam Marszałek.

Gwizdała, J.P. (2015). Euroregiony jako forma współpracy transgranicznej w Europie. Zeszyty Naukowe Uniwersytetu Szczecińskiego. Finanse, Rynki Finansowe, Ubezpieczenia, 74 (2), 449-450.

https://web.facebook.com/czechofile/?_rdr (5.05.2018).

Komunikat z badań CBOS. Aktywność Polaków w organizacjach obywatelskich, nr 13/2016. Pobrane z: https://www.cbos.pl/SPISKOM.POL/2016/K_013_16.PDF (5.05.2018). 
Komunikat z badań CBOS. Aktywność społeczna Polaków, nr 60/2014. Pobrane z: https:// www.cbos.pl/SPISKOM.POL/2014/K_060_14.PDF (5.05.2018).

Komunikat z badań CBOS. Potencjał społecznikowski oraz zaangażowanie w pracę społecznq, nr 15/2016. Pobrane z: https://www.cbos.pl/SPISKOM.POL/2016/K_015_16. PDF (5.05.2018).

Komunikat z badań CBOS. Stosunek do innych narodów, nr 2018/37. Pobrane z: https:// www.cbos.pl/SPISKOM.POL/2018/K_037_18.PDF (5.05.2018).

Lewowicki, T., Szczurek-Boruta, A., Szafrańska, A. (2017). Sfery życia duchowego dzieci, młodzieży i dorosłych - studium z pogranicza polsko-czeskiego. O nauczycielach, ich spostrzeganiu świata społecznego i aktywności, t. 4. Cieszyn-Toruń: Wydział Etnologii i Nauk o Edukacji Uniwersytetu Śląskiego, Wydawnictwo Adam Marszałek.

Marzec-Holka, K. (2015). Peryferie edukacyjne szkół wiejskich w warunkach niżu demograficznego. Pedagogika Społeczna, 3.

Mazan, L. (2007). Polska Praga, czyli dlaczego Matejko lubił knedle. Kraków: Oficyna Wydawnicza "Anabasis".

MSWiA, Strefa Schengen. Pobrane z: https://www.mswia.gov.pl/pl/aktualnosci/5087,dok. html (5.05.2018).

Piwowarski, R. (2000). Szkoły na wsi - edukacyjne wyzwanie. Warszawa: Instytut Badań Edukacyjnych.

Rusek, H. (2004). Wyszehradzkie sq̨siedztwa: Przypadek polsko-czeski. W: R. Zenderowski (red.), Europa Środkowa: wspólnota czy zbiorowość? (s. 106). Wrocław-WarszawaKraków: Zakład Narodowy im. Ossolińskich.

Sadowski, A. (2008). Pogranicze - pograniczność - tożsamość pogranicza. W: H. Bojar, D. Wojakowski, A. Sadowski (red.), Polskie granice i pogranicza. Nowe problemy i interpretacje. Pogranicze. Studia Społeczne, t. XIV. Białystok: Wydawnictwo Uniwersytetu w Białymstoku.

Surosz, M. (2010). Pepiki. Dramatyczne stulecie Czechów. Warszawa: Wydawnictwo W.A.B.

Szczygieł, M. (2006). Gottland. Wołowiec: Wydawnictwo Czarne.

Szczygieł, M. (2010). Zrób sobie raj. Wołowiec: Wydawnictwo Czarne.

Szczygieł, M. (2012). Láska nebeská. Warszawa: Wydawnictwo Agora S.A.

Witkowski, L. (1991). Uniwersalizm pogranicza. O semiotyce kultury Michała Bachtina w kontekście edukacji. Toruń: Wyd. Adam Marszałek.

Witkowski, L. (1995). Ambiwalencje tożsamości z pogranicza kulturowego. W: M.M. Urlińska (red.), Edukacja a tożsamość etniczna (s. 18). Toruń: Wyd. UMK. 